

\section{DISCLAIMER}

This report was prepared as an account of work sponsored by an agency of the United States Government. Neither the United States Government nor any agency Thereof, nor any of their employees, makes any warranty, express or implied, or assumes any legal liability or responsibility for the accuracy, completeness, or usefulness of any information, apparatus, product, or process disclosed, or represents that its use would not infringe privately owned rights. Reference herein to any specific commercial product, process, or service by trade name, trademark, manufacturer, or otherwise does not necessarily constitute or imply its endorsement, recommendation, or favoring by the United States Government or any agency thereof. The views and opinions of authors expressed herein do not necessarily state or reflect those of the United States Government or any agency thereof. 


\section{DISCLAIMER}

Portions of this document may be illegible in electronic image products. Images are produced from the best available original document. 
Printed in the United States of America. Available from National Technical Information Service

U.S. Department of Commerce

5285 Port Royal Road, Springfield, Virginia 22161

Price: Printed Copy $\$ 4.00$; Microfiche $\$ 3.00$

This report was prepared as an account of work sponsored by an agency of the United States Government. Neither the United States Government nor any agency thereof, nor any of their employees, nor any of their contractors, subcontractors, or their employees, makes any warranty, express or implied, nor assumes any legal liability or responsibility for any third party's use or the results of such use of any information, apparatus, product or process disclosed in this report, nor represents that its use by such third party would not infringe privately owned rights. 
Date of Issue: March 21, 1978

Distribution Category: UC-37

\title{
A VIDEO MONITORING SYSTEM FOR ENRICHED URANIUM CASTING FURNACES
}

\author{
P. C. Turner \\ Instrumentation and Characterization Department \\ Y-12 Dovelopment nivisinn
}

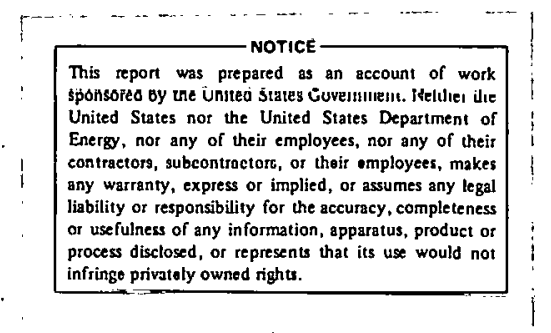

Oak Ridge Y-12 Plant

P. O. Box Y, Oak Ridge, Tennessee 37830

Prepared for the Department of Energy Under US Government Contract W-7405-eng-26 


\begin{abstract}
A closed-circuit television (CCTV) system was developed to upgrade the remote-viewing capability on two oralloy (highly enriched uranium) casting furnaces in the Y-12 Plant. A silicon vidicon CCTV camera with a remotely controlled lens and infrared filtering was provided to yield a good-quality video presentation of the furnace crucible as the oralloy material is heated from 25 to $1300^{\circ} \mathrm{C}$. Existing tube-type CCTV monochrome monitors were replaced with solid-state monitors to increase the system reliability.
\end{abstract}




\section{CONTENTS}

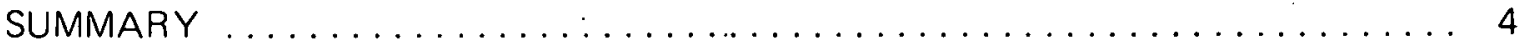

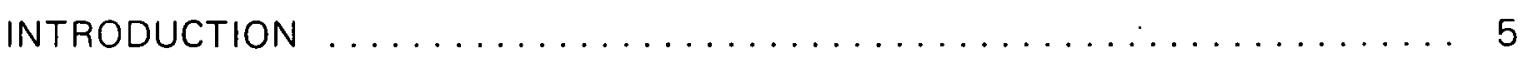

VIDEO MONITOR FOR CASTING FURNACES $\ldots \ldots \ldots \ldots \ldots \ldots \ldots \ldots \ldots$

Experimental Study and Observations . . . . . . . . . . . . . . . . 7

Upgrading the Video System . . . . . . . . . . . . . . . . . . . . . . 7

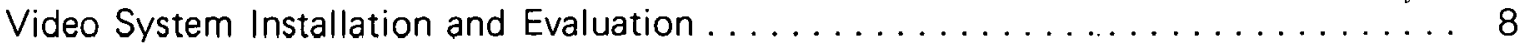

ACKNOWLEDGEMENTS ............................ 10 


\section{SUMMARY}

Closed-circuit television (CCTV) systems used for monitoring the induction casting of oralloy in the Oak Ridge $\mathrm{Y}-12$ Plant were not yielding adequate video presentations of the melting material as it was heated from 25 to $1300^{\circ} \mathrm{C}$. An experiment was performed to determine the light-level compensation range needed to maintain a good contrast picture as the material's incandescence changed during the heating process. This experiment showed that a 20,000:1 compensation range was required. Since the compensation range of the existing cameras was only 4000:1, new cameras were specified and installed. Existing tube-type video monitors were also replaced with new solid-state monitors to improve the overall reliability of the system. Operational tests of the new CCTV systems produced good-quality video presentations as the furnace was heated from 25 to $1300^{\circ} \mathrm{C}$. 


\section{INTRODUCTION}

Two induction furnaces are used by the Metal Preparation Division of the Oak Ridge Y-12 Plant ${ }^{(a)}$ for casting oralloy billets. Since these furnaces are housed within neutron vaults to provide a safe working environment, remote operation of all in-process furnace monitoring and control equipment is necessary. Figure 1 is an illustration of a typical induction furnace.

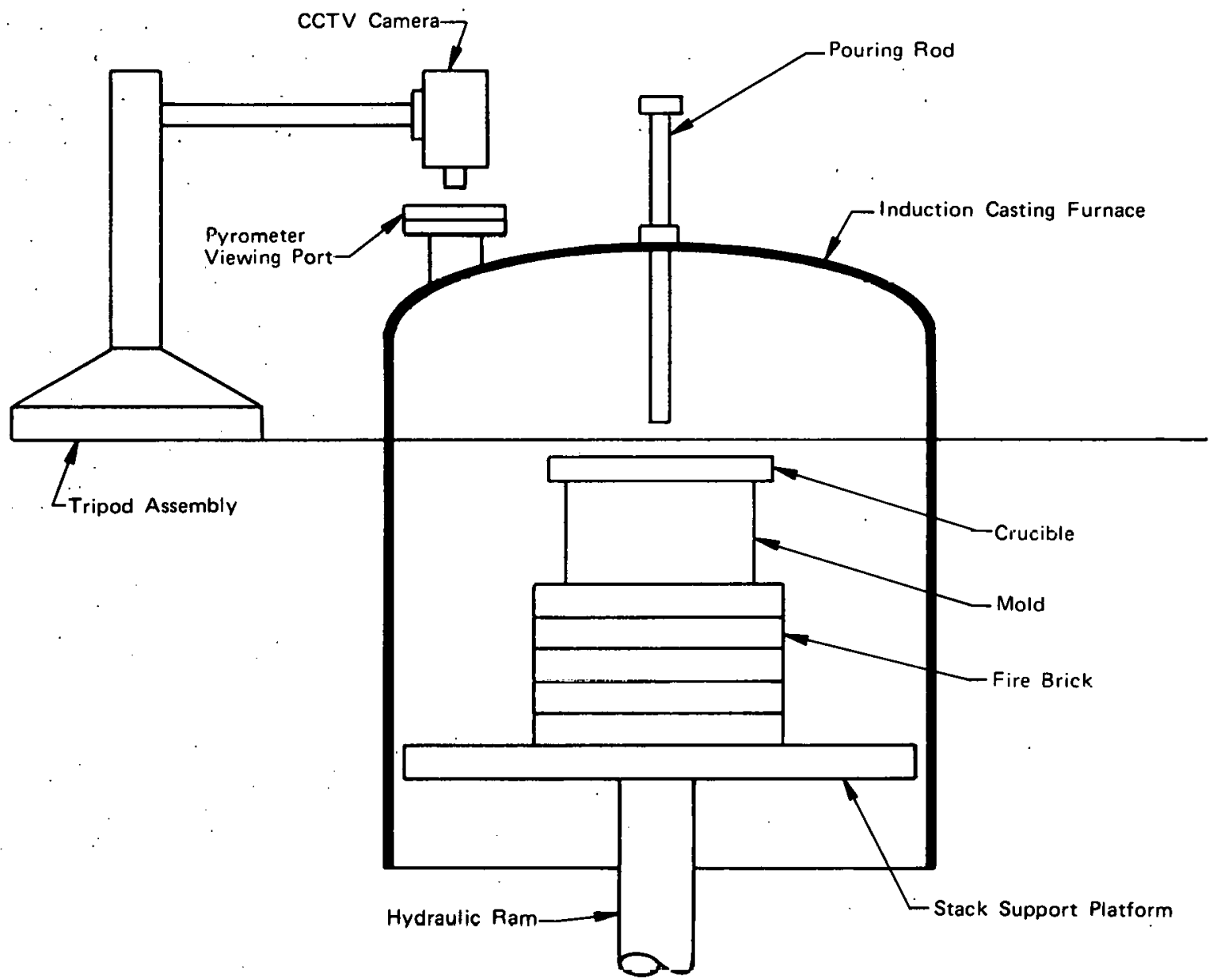

Figure 1. EXPERIMENTAL CLOSED-CIRCUIT TELEVISION ARRANGEMENT FOR VIEWING AN INDUCTION CASTING OPERATION.

Each furnace has two monochrome CCTV systems to provide remote visual verification of in-process operations. One CCTV system is used for observing the stack-loading operation at the bottom of each furnace. (Arrangement of the fire brick, mold, and crucible is called the "stack".) A second CCTV system provides a view of the top of the crucible to verify two

(a) Operated by the Union Carbide Corporation's Nuclear Division for the Department of Energy. 
important events during a normal furnace-melting cycle: (1) proper thermocouple positioning within its receptable in the crucible, and (2) conformation of molten material flow from the crucible to the mold. Thermocouple position is critical to obtaining a precise measurement of the crucible temperature; which, in turn, affects the material purity: The only positive way to know that material. has flowed into the mold is by observing the crucible during the pouring event.

There were two problems associated with the second CCTV system (used for observing the crucible in each furnace): (1).a good contrast picture of the crucible could not be maintained as the material was heated from 25 to $1300^{\circ} \mathrm{C}$; (2) the existing camera vidicon tube was subject to image burn in and target damage when expösed to high-intensity illumination from the incandescent oralloy and crucible. This report describes the action taken to correct these problems. 


\section{VIDEO MONITOR FOR CASTING FURNACES}

\section{EXPERIMENTAL STUDY AND OBSERVATIONS}

As noted in Figure 1, an existing CCTV camera was temporarily positioned over the glass port normally used to measure the crucible temperatures with an optical pyrometer. This set up made it possible to determine the illumination range needed to maintain good-quality video presentations during casting operations. A CCTV monitor and video-tape recorder were interconnected to the camera, and a $50-\mathrm{mm}, \mathrm{f} / 1.8$ lens was installed. Three neutral-density filters of 1,10 , and $24 \%$ transmission; four narrow-bandpass filters passing wavelengths of $561,610,828$, and $1057 \mathrm{~nm}$, and an infrared blocking filter were used in various combinations throughout the experiment.

Three typical casting operations were observed and recorded. During each operation, the crucible was observed as its temperature ranged from 25 to $1300^{\circ} \mathrm{C}$. Thermocouple positioning, material melting, and material flow from curcible to mold were observed. Throughout the casting operation, several combinations of lens aperture and filters were tried and correlated with the video recording.

From these experiments, the following information was obtained:

1. Using only neutral-density filtering, an illumination adjustment range of $1.4 \times 10^{6}: 1$ was required for good contrast video.

2. By employing infrared blocking filters, which provide $10^{6}$ attenuation of radiated energy above a $1-\mu \mathrm{m}$ wavelength, an illumination adjustment range of 20,000:1 was adequate for maintaining good contrast video.

3. Narrow-bandpass filters, having the wavelengths previously listed, provided little advantage in this application.

\section{UPGRADING THE VIDEO SYSTEM}

Since the existing CCTV camera had only a 4000:1 illumination adjustment range, a new CCTV system was recommended. Specifications for the new camera include: (1) a 20,000:1 automatic illumination adjustment range, (2) a 15 to $150-\mathrm{mm}$ f/2.5 zoom lens with remote control of the zoom, focus, and manual iris override movements, and (3) a silicon vidicon image tube which has a high resistance to image burn in and target damage due to high-level illumination. Two infrared blocking filters, each having $10^{3}$ attenuation for wavelengths above $1 \mu \mathrm{m}$, were used to prevent vidicon saturation. To increase the overall reliability of 
each CCTV system, monochrome CCTV monitors were recommended to replace the existing tube-type monitors. Figure 2 provides a pictorial representation of the crucible monitoring system.

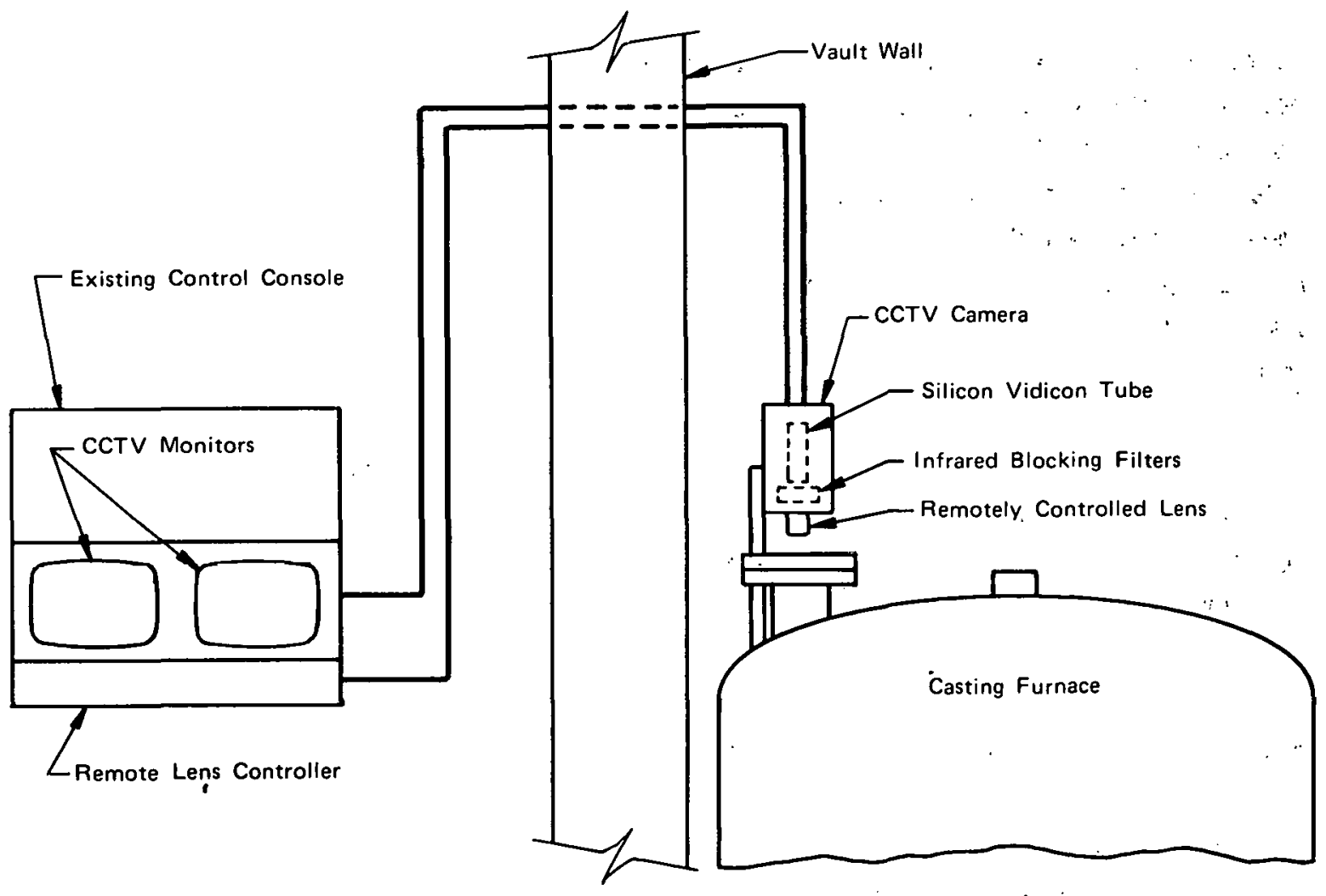

Figure 2. REPRESENTATION OF THE CRUCIBLE CLOSED-CIRCUIT TELEVISION MONITORING SYSTEM.

\section{VIDEO SYSTEM INSTALLATION AND EVALUATION}

After procuring all camera components, two CCTV systems were installed on the oralloy casting furnaces. An adjustable camera-mounting fixture was designed with the aid of Metal Preparation Division personnel, and one fixture was welded to the top of each furnace. Figures 3 and 4 provide views of these installations. Alignment of each camera was facilitated by using a portable CCTV monitor within the vault to achieve the desired view of the crucible and thermocouple. A typical view of the crucible area is seen in Figure 5.

Evaluation of each CCTV system consisted of an initial test of all system functions, and an operational test consisting of observing the crucible during a typical casting sequence. All remote controls functioned properly during the initial test, after minor adjustments of the electrical and optical components were completed. During the operational test, each furnace' was heated until the crucible temperature changed from 25 to $1300^{\circ} \mathrm{C}$. The automatic illumination adjustment of each camera maintained a high-resolution, good-contrast video 


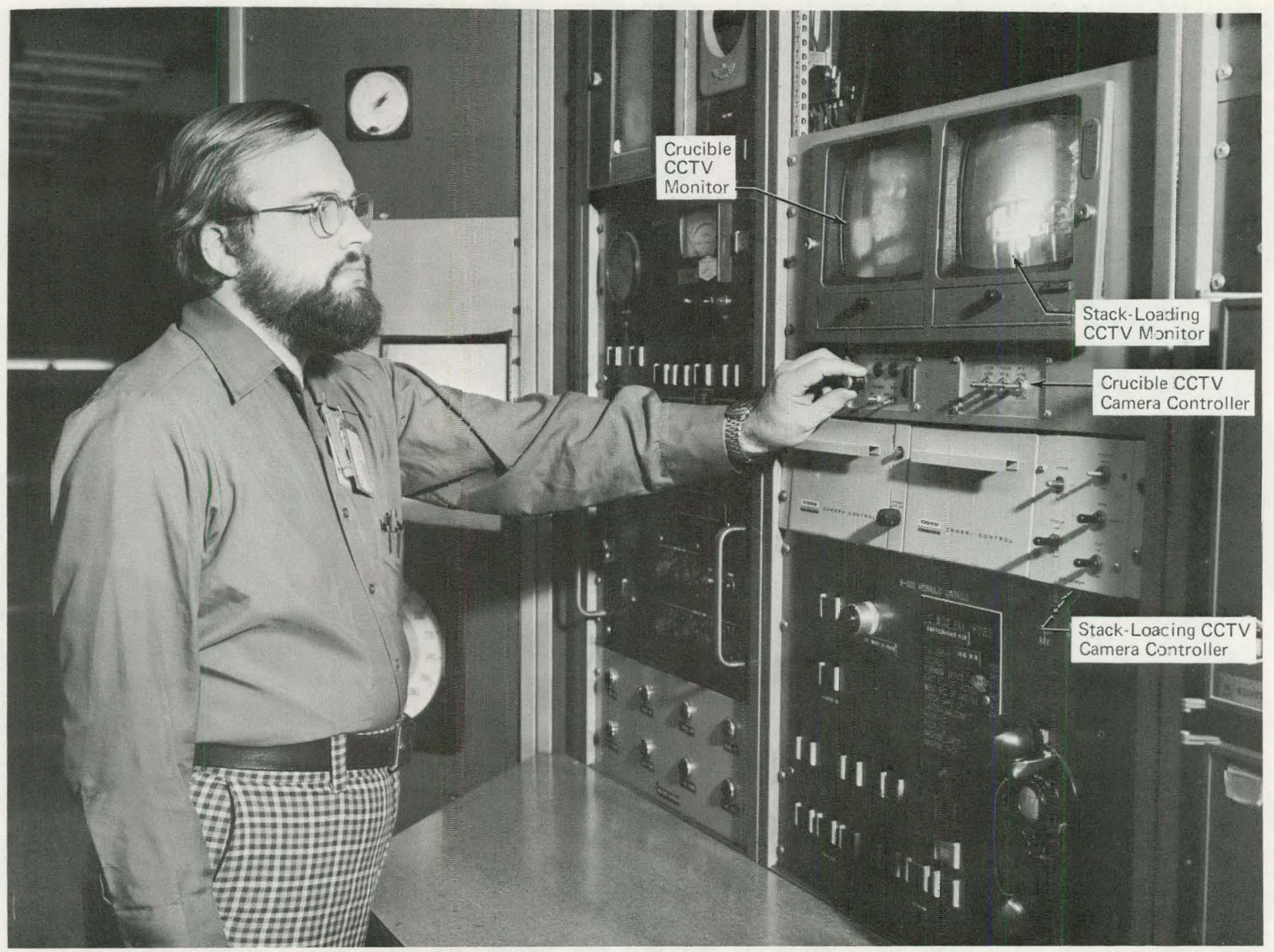

Figure 3. CLOSED-CIRCUIT TELEVIS ON CONTROLS AND MONITORS FOR THE JRALLOY CASTING FURNACE.

177010 


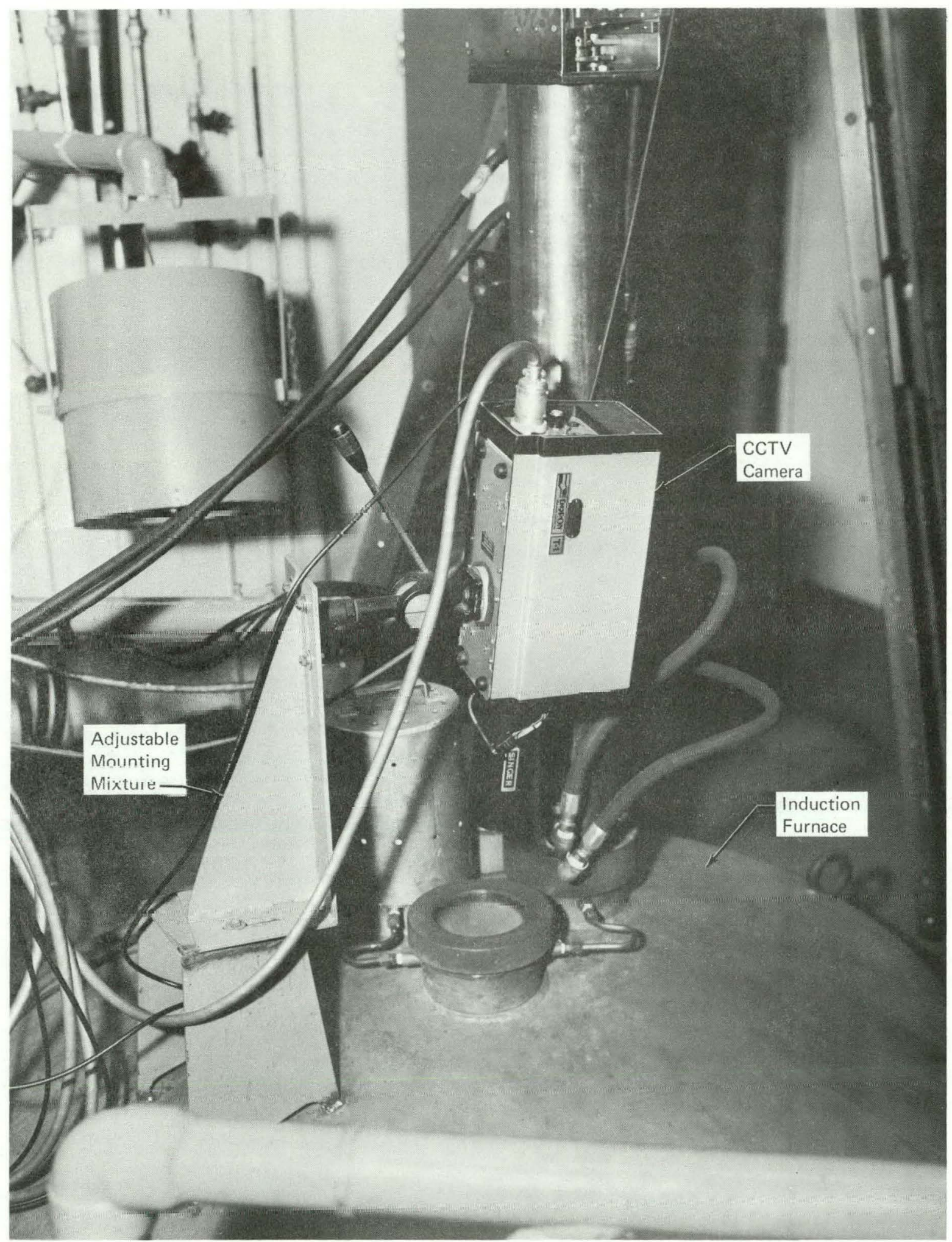

177011

Figure 4. CRUCIBLE-MONITORING CLOSED-CIRCUIT TELEVISION CAMERA FOR THE ORALLOY CASTING FURNACE. 


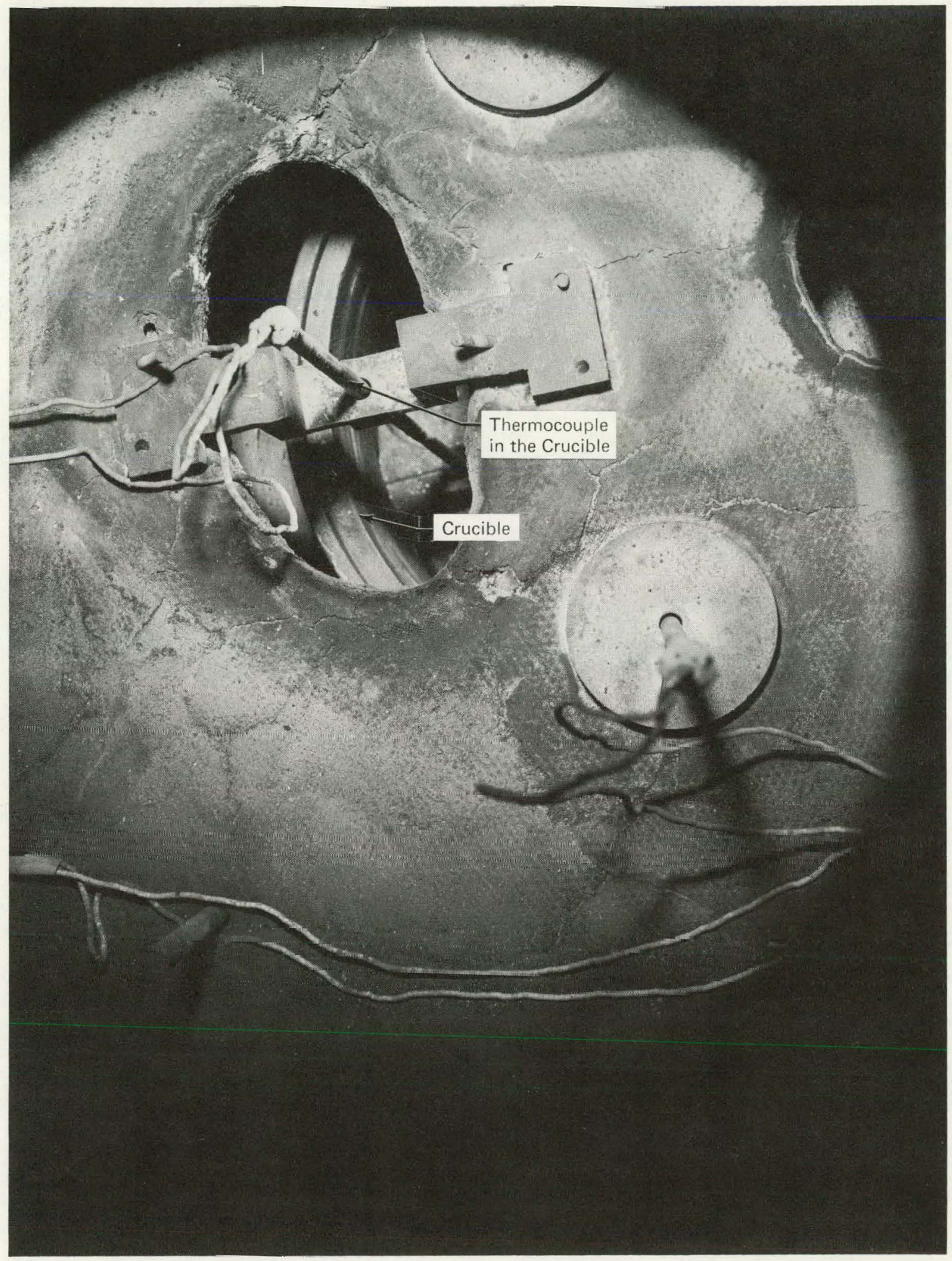

177012

rigure 5. TYPICAL VILW OF THE ORALLOY-CASTING-FURNACE CRUCIBLE. 
presentation throughout the heating cycle. With testing complete, the CCTV systems were integrated into the normal casting activities. 


\section{ACKNOWLEDGEMENTS}

The author wishes to express special thanks to J. H. Burkhardt, Jr for his efforts during the early phases of this project and to P. E. Reagan for his assistance in designing the camera-mounting fixture. 


\section{Distribution}

Department of Energy - Albuquerque

Vespe, V.C.

Department of Energy - Oak Ridge

Hickman, H. D.

Zachry, D. S., Jr

\section{Lawrence Livermore Laboratory}

Nelson, W. E.

Technical Information Division Library

Los Alamos Scientific Laboratory

Hoyt, H. C.

Library Services

Oak Ridge Gaseous Diffusion Plant

Stief, S. S.

Wilcox, W. J., Jr

Oak Ridge National Laboratory

Weir, J. R., Ji

Oak Ridge Y-12 Plant

Armstrong, R. C.

Barkman, J. R.

Bernander, N. K.

Bostock, D. J.

Dodson, W. H.

Duggan, H. G.

Fraser, R. J.

Guinn, G. R.

Jones, F. W.

Kahl, K. G.

Keith, A.

Kite, H. T. (15)

Marrow, G. B.

Martin, W. R./Googin, J. M.

Mason, D. L./Schreyer, J. M.

Milis, J. M., Jr

Minton, J. L.

Phillips, L. R.
Reagan, P. E.

Smith, H. F., Jr

Smith, R. D.

Smith, W. E.

Stephens, A. E.

Stoner, H. H.

Tewes, W. E.

Thompson, W. H., Jr

Turner, P. C. (4)

White, J. C.

Whitson, W. K.

Williams, R. D.

Yaggi, W. J.

Y-12 Central Files (master copy)

Y-12 Central Files (route copy)

$Y-12$ Central Files ( $Y-12 R C$ )

$Y-12$ Central Files (5)

Paducah Gaseous Diffusion Plant

Bewley, H. D.

Sandia - Albuquerque

Mail Service Section

Sandia - Livermore

Technical Library

Union Carbide Corporation - New York

Wliniers, c.

In addition, this report is distributed in accordance with the category UC-37. Instruments, as given in the USERDA Standard Distribution Lists for Unclassified Scientific and Technical Reports, TID 4500. 